\title{
Searching for "monogenic diabetes" in dogs using a candidate gene approach
}

\author{
Andrea D Short ${ }^{1 *}$, Angela Holder ${ }^{2}$, Simon Rothwell ${ }^{1}$, Jonathan Massey ${ }^{1}$, Rachel Scholey ${ }^{1}$, Lorna J Kennedy ${ }^{1}$, \\ Brian Catchpole ${ }^{2}$ and William ER Ollier ${ }^{1}$
}

\begin{abstract}
Background: Canine diabetes is a common endocrine disorder with an estimated breed-related prevalence ranging from $0.005 \%$ to $1.5 \%$ in pet dogs. Increased prevalence in some breeds suggests that diabetes in dogs is influenced by genetic factors and similarities between canine and human diabetes phenotypes suggest that the same genes might be associated with disease susceptibility in both species. Between 1-5\% of human diabetes cases result from mutations in a single gene, including maturity onset diabetes of the adult (MODY) and neonatal diabetes mellitus (NDM). It is not clear whether monogenic forms of diabetes exist within some dog breeds. Identification of forms of canine monogenic diabetes could help to resolve the heterogeneity of the condition and lead to development of breed-specific genetic tests for diabetes susceptibility.

Results: Seventeen dog breeds were screened for single nucleotide polymorphisms (SNPS) in eighteen genes that have been associated with human MODY/NDM. Six SNP associations were found from five genes, with one gene (ZFP57) being associated in two different breeds.

Conclusions: Some of the genes that have been associated with susceptibility to MODY and NDM in humans appear to also be associated with canine diabetes, although the limited number of associations identified in this study indicates canine diabetes is a heterogeneous condition and is most likely to be a polygenic trait in most dog breeds.
\end{abstract}

Keywords: Diabetes mellitus, Dog breeds, Candidate genes

\section{Lay summary}

Diabetes is a common condition where sugar (glucose) levels of the body are poorly regulated, due to either lack of production of the hormone insulin, made in the pancreas, or an increase in resistance of tissues in the body to the effects of insulin. Canine diabetes is similar to some forms of human diabetes; it is relatively common in dogs, and its prevalence (the proportion of dogs affected at a point in time) ranges from $0.005 \%$ to $1.5 \%$, and is dependent on which breed is being considered. This breed-related variation in the prevalence of diabetes suggests a genetic basis in dogs.

In humans, some forms of diabetes are due to mutations in just a single gene (these are called monogenic conditions). This study examined 18 genes that are known to be

\footnotetext{
* Correspondence: andrea.short@manchester.ac.uk

${ }^{1}$ Centre for Integrated Genomic Medical Research, University of Manchester, Stopford Building, Oxford Road, Manchester M13 9PT, UK

Full list of author information is available at the end of the article
}

associated with human monogenic diabetes, and tested whether they are also associated with diabetes in 17 different dog breeds.

Six variants from five genes were found to be associated with diabetes in some breeds. Interestingly, two different variants in the same gene (called ZFP57 - Zinc finger protein 57) were associated with diabetes in two different breeds.

\section{Background}

Canine diabetes is a common endocrine disorder with an estimated prevalence ranging from $0.005 \%$ to $1.5 \%$ [1]. Almost all diabetic dogs require exogenous insulin therapy to manage their hyperglycaemia, often resulting from insulin deficiency leading to the inability to control their blood glucose concentration. Canine diabetes has been compared with human type 1 diabetes (T1D) $[2,3]$ as they share many clinical and pathophysiological features. However, in contrast with T1D, which is usually 
diagnosed in young patients $(<30$ years of age), canine insulin-deficiency diabetes (IDD) occurs more commonly in older dogs, aged 7-12 years [4].

The aetiology and underlying pathogenesis of canine IDD has not been fully determined, although exocrine pancreatic disease $[5,6]$ and immune-mediated mechanisms [7] are suspected to be underlying causes of pancreatic beta cell destruction. It has been also been suggested that, in many ways, canine diabetes resembles latent autoimmune diabetes of the adult (LADA) in man [8], a more slowly progressive form of autoimmune diabetes.

Pedigree dog breeds, similar to some ethnic groups in the human population [9], display variability in diabetes susceptibility, with some breeds (e.g. Samoyed) being over-represented, whereas others (e.g. Boxer) seem to be relatively resistant to developing the disease [10]. These breed-related differences in diabetes susceptibility suggest that the pathogenesis of diabetes is influenced by genetic factors and similarities between canine and human diabetes phenotypes indicate that the same genes and/or genetic pathways might be involved in both species. Since some phenotypes also appear to be somewhat breedspecific [11], for example NDM, in Keeshond dogs [12] and dioestrus diabetes in female entire Elkhounds and Lapphunds [13], there could be differences in the individual susceptibility genes that contribute to the overall genetic risk for different dog breeds, as is seen with different ethnic groups and type 2 diabetes in humans [14].

A small proportion of human diabetic patients suffer from disease resulting from mutation(s) in a single gene. These monogenic forms of diabetes account for around $1-5 \%$ of human diabetes cases and include maturity onset diabetes of the young (MODY) and neonatal diabetes mellitus (NDM) [15]. MODY represents a heterogeneous group of disorders that are commonly diagnosed before 25 years of age in humans. They result from autosomal dominant mutations in genes that control the synthesis or secretion of insulin by the pancreatic beta cells and include HNF4A (MODY1) [16], GCK (MODY2) [17,18], HNF1A (MODY3) [19,20], PDX1 (MODY4) [21] and HNF1B (MODY5) [22]. NDM is commonly diagnosed around 6 months of age in humans and can be the result of sporadic or inherited (autosomal dominant) mutations in certain genes, including $K C N J 11, A B C C 8$ and insulin (INS) $[23,24]$. Mutations in the glucokinase $(G C K)$ gene can also lead to NDM [25].

Although the majority of diabetic dogs $(>90 \%)$ are diagnosed in animals over 6 years of age [26], within the population of young diabetic dogs (diagnosed $<6$ years), there is a clear breed-related overrepresentation of Golden and Labrador Retrievers [26]. Screening for mutations in canine KCNJ11 and INS have not so far identified any genetic anomalies in a cohort of dogs in the United Kingdom that were affected with NDM (Catchpole unpublished data). NDM has been reported in a small number of dog breeds in the USA [27], including an inherited form in Keeshonds, where the specific genetic defect was not identified, but which is believed to be inherited in an autosomal recessive manner [12].

While the domestication of the dog from the wolf is believed to have occurred some 15,000-200,000 years ago [28], most modern pedigree dog breeds have been created in the last 300 years and represent distinct, genetically segregated populations with high levels of inbreeding and reduced heterogeneity. The relatively short time frame taken to establish modern breeds has been insufficient for chromosomal restructuring to take place and as a result of this, they have extended linkage disequilibrium (LD) and long haplotype blocks within a breed [29]. The selection bias for 'desirable' morphological and behavioural traits (hunting instinct, head shape etc.) that has been used to create modern breeds has resulted in a concentration of the gene(s) associated with the trait within a given breed. Inadvertently, disease-associated genes have also been concentrated alongside the morphological and behavioural traits, resulting in each breed demonstrating highly variable disease incidences for particular conditions [30,31].

Identification of a monogenic type of diabetes in a particular dog breed could lead to the development of a breed-specific genetic test for diabetes susceptibility.

To date, the genes that have been identified as causing monogenic types of diabetes in humans have not been evaluated in the diabetic dog population, where it is possible that some breeds may express a monogenic form of the condition. The aim of the present study was to screen single nucleotide polymorphisms (SNPs) from eighteen genes that have been associated with human MODY/ NDM in seventeen dog breeds in order to resolve, at least in part, canine diabetes breed-related genetic susceptibilities. Although samples sizes were relatively small for some breeds examined it has been recognised that only $20-50$ affected dogs are usually required for identifying conditions with a monogenic aetiology [32].

\section{Results}

\section{Data quality}

Twelve of the 65 genotyped SNPs were excluded prior to analysis because of high failure rates or improper clustering, leaving 53 SNPs for analysis in each breed. Excluded assays were: rs24533550 (Cel), rs22588616, rs9179252 (EIF2AK3), rs22686866 (INS), rs22686870 (INS) rs8516455 (KCNJ11), rs8516454 (KCNJ11), rs897 1148 (PAX4), rs9089163 (PDX1), rs21958943 (RFX6), rs22261809 (WFS1), rs23916066 (ZFP7). The final number of SNPs that passed QC for each breed is shown in Table 1, in addition to the total number of cases and controls for each breed that were genotyped and that the number that subsequently passed QC. 
Table 1 Breeds used in the study and overview of SNP analysis

\begin{tabular}{|c|c|c|c|c|c|}
\hline \multirow[b]{2}{*}{ Breed } & \multicolumn{2}{|c|}{ Case (n) } & \multicolumn{2}{|c|}{ Control (n) } & \multirow{2}{*}{$\begin{array}{c}\text { SNPs (n) } \\
\text { After } \\
\text { QC }\end{array}$} \\
\hline & Genotyped & $\begin{array}{l}\text { After } \\
\text { QC }\end{array}$ & Genotyped & $\begin{array}{l}\text { After } \\
\text { QC }\end{array}$ & \\
\hline Bichon Frise & 29 & 28 & 29 & 29 & 47 \\
\hline Border collie & 82 & 76 & 82 & 79 & 49 \\
\hline Border terrier & 26 & 24 & 28 & 25 & 50 \\
\hline Cairn terrier & 45 & 42 & 45 & 39 & 52 \\
\hline $\begin{array}{l}\text { Cavalier King } \\
\text { Charles Spaniel }\end{array}$ & 52 & 50 & 55 & 46 & 51 \\
\hline Cocker Spaniel & 63 & 58 & 66 & 66 & 44 \\
\hline Doberman & 18 & 17 & 19 & 18 & 51 \\
\hline Jack Russell terrier & 61 & 58 & 60 & 54 & 45 \\
\hline Labrador Retriever & 153 & 136 & 155 & 155 & 46 \\
\hline $\begin{array}{l}\text { Miniature } \\
\text { Dachshund }\end{array}$ & 39 & 37 & 40 & 39 & 47 \\
\hline $\begin{array}{l}\text { Miniature } \\
\text { Schnauzer }\end{array}$ & 32 & 29 & 31 & 29 & 49 \\
\hline Samoyed & 41 & 40 & 84 & 74 & 50 \\
\hline Springer Spaniel & 22 & 21 & 25 & 25 & 48 \\
\hline $\begin{array}{l}\text { Staffordshire Bull } \\
\text { terrier }\end{array}$ & 15 & 14 & 15 & 15 & 52 \\
\hline Tibetan terrier & 30 & 30 & 30 & 30 & 51 \\
\hline $\begin{array}{l}\text { West Highland } \\
\text { White terrier }\end{array}$ & 135 & 123 & 135 & 129 & 45 \\
\hline Yorkshire terrier & 79 & 76 & 80 & 75 & 47 \\
\hline Total & 922 & 859 & 979 & 927 & \\
\hline
\end{tabular}

\section{Allele association}

Allelic analysis identified six SNPs associated with canine diabetes in this study (Table 2). ZFP57 was associated with canine diabetes in two different breeds, although the associated marker was different: Bichon Frise (rs23901704) and Samoyed (rs23892119) (Table 2). Diabetes in Cocker Spaniels showed an association with three SNPs from three different genes: MTTL1 (rs243 05581), PAX4 (rs22302353) and INS (rs22686871) and in the miniature Dachshund there was a single association with HNF4A (rs8804236).

Of the associated SNPs, three were intronic (rs24305581, rs22302353, rs23892119) and three were synonymous coding SNPs, (rs23901704, rs22686871 rs8804236, Table 2).

\section{Genotype association}

Genotype analysis revealed a significant association with all of the SNPs identified above $(p<0.05$, Figure 1$)$. In the Bichon Frise, the ' $T$ ' allele of SNP rs23901704 was associated with reduced risk for diabetes, with the TT and TC genotypes being found in $4.8 \%$ and $38.1 \%$ of the controls respectively. These two genotypes were not found in any of the cases, where all of the diabetic dogs of this breed carried the CC genotype compared to $57.1 \%$ of the controls (Figure 1). In the Samoyed, the ' $\mathrm{C}$ ' allele of SNP rs23892119 was associated with increased risk for diabetes and represented $11 \%$ of the case population alleles; this allele was not found in the controls (Table 2). For the genotype frequencies, the ' $\mathrm{C}$ ' allele was found in only a small proportion of the case population with the TC and CC genotypes representing only $11.4 \%$ and $5.7 \%$, respectively. The TT genotype represented $100 \%$ of the control genotypes and $82.9 \%$ of the case genotypes (Figure 1). The 'G' allele of SNP rs8804236 was associated with diabetes in the Miniature Dachshund (Table 2). It represented $14 \%$ of the case alleles and $36 \%$ of the control alleles and the GG homozygous genotype was more common in the control population $(29.6 \%)$ than in the cases $(2.7 \%)$. The GA heterozygous genotype was more common in the cases (21.6\%) than the controls (3.8\%); the AA homozygous genotype represented $75.5 \%$ and $69.2 \%$ of the cases and controls respectively (Figure 1).

Three SNPs were associated with diabetes in the Cocker Spaniel breed (Table 2). For SNPs rs22302353 and rs22686871, the major allele homozygote (GG and TT respectively) was more common in the cases than the controls and for rs22686871, it represented $100 \%$ of the case genotypes, compared to $78.5 \%$ of the controls (Figure 1). For SNP rs24305581, the minor allele ('A') was found in $69.7 \%$ of the case genotypes $(A A+A G)$ vs. $39.4 \%$ of the control genotypes and the GG genotype was more common in the controls $(60.6 \%)$ than the cases (29.3\%, Figure 1). The heterozygous genotype for this SNP represented more than $50 \%$ of the case genotypes but only $33.3 \%$ of the control genotypes. Analysis of genotype combinations across these three associated markers in this breed did not identify any genotype combinations that were more or less common in either the case or the control populations, indicating that the associations are independent of each other (data not shown).

\section{Discussion}

Some cases of canine diabetes share several similarities with the monogenic forms of human diabetes, known as maturity onset diabetes of the young (MODY). To date, however, there is no reported evidence of monogenic diabetes association studies in dogs. We identified six canine allelic associations to genes that are causative for human monogenic forms of diabetes, but none of these associations can fully explain diabetes risk in any given dog breed. One gene (ZFP57) was associated with two different SNPs in two disparate breeds (Bichon Frise and Samoyed) and one breed (Cocker Spaniel) had an association with three SNPs from three different genes (MTTL1, $P A X 4, I N S)$. The allele and genotype frequencies do not indicate that these associations explain the full susceptibility to canine breed-related diabetes and suggest that 
Table 2 Allelic associations

\begin{tabular}{|c|c|c|c|c|c|c|c|c|c|c|c|c|c|}
\hline & \multirow[b]{2}{*}{ Gene } & \multirow[b]{2}{*}{ CFA } & \multirow[b]{2}{*}{ Position (bp) } & \multirow[b]{2}{*}{ Annotation } & \multirow{2}{*}{$\begin{array}{l}\text { Minor/associated } \\
\text { allele }\end{array}$} & \multicolumn{2}{|c|}{ Frequency } & \multirow{2}{*}{$\begin{array}{l}\text { Major } \\
\text { allele }\end{array}$} & \multicolumn{3}{|c|}{$p$-values } & \multirow{2}{*}{$\begin{array}{l}\text { Odds } \\
\text { ratio }\end{array}$} & \multirow[b]{2}{*}{$95 \% \mathrm{Cl}$} \\
\hline & & & & & & Case & Control & & Raw & Bonferroni & Permutation & & \\
\hline \multicolumn{14}{|l|}{ Bichon Frise } \\
\hline rs23901704 & ZFP57 & 35 & $26,267,827$ & Syn. coding & T & 0.00 & 0.24 & C & $2.58 \mathrm{E}-04$ & $7.21 \mathrm{E}-03$ & 4.30E-03 & $\mathrm{nc}$ & $\mathrm{nc}$ \\
\hline \multicolumn{14}{|c|}{ Cocker Spaniel } \\
\hline rs24305581 & MTTL1 & 5 & $82,755,249$ & Intronic & A & 0.44 & 0.23 & G & 3.73E-04 & 1.05E-02 & $1.13 \mathrm{E}-02$ & 2.67 & $1.54-4.61$ \\
\hline rs 22302353 & PAX4 & 14 & $8,718,207$ & Intronic & A & 0.09 & 0.33 & G & $6.45 \mathrm{E}-06$ & $1.81 \mathrm{E}-04$ & $3.00 \mathrm{E}-04$ & 0.21 & $0.10-0.43$ \\
\hline rs 22686871 & INS & 18 & $46,324,586$ & Syn. coding & G & 0.00 & 0.13 & T & 7.22E-05 & $2.02 \mathrm{E}-03$ & $1.90 \mathrm{E}-03$ & $\mathrm{nc}$ & $\mathrm{nc}$ \\
\hline \multicolumn{14}{|c|}{ Miniature Dachshund } \\
\hline rs8804236 & HNF4A & 24 & $31,897,491$ & Syn. coding & G & 0.14 & 0.36 & A & $1.45 \mathrm{E}-03$ & 4.62E-02 & 4.31E-02 & 0.28 & $0.12-0.63$ \\
\hline \multicolumn{14}{|l|}{ Samoyed } \\
\hline rs23892119 & ZFP57 & 35 & $26,270,002$ & Intronic & C & 0.11 & 0.00 & T & $1.55 \mathrm{E}-04$ & 5.10E-03 & 5.50E-03 & $\mathrm{nc}$ & $\mathrm{nc}$ \\
\hline
\end{tabular}

CFA = canine chromosome number: Permutations: $n=10,000: \mathrm{Cl}=$ confidence interval: Syn. Coding = synonymous coding SNP; $n c=$ not calculable as one of the populations does not carry one of the alleles. Allele associations are calculated using the minor allele as a reference. 


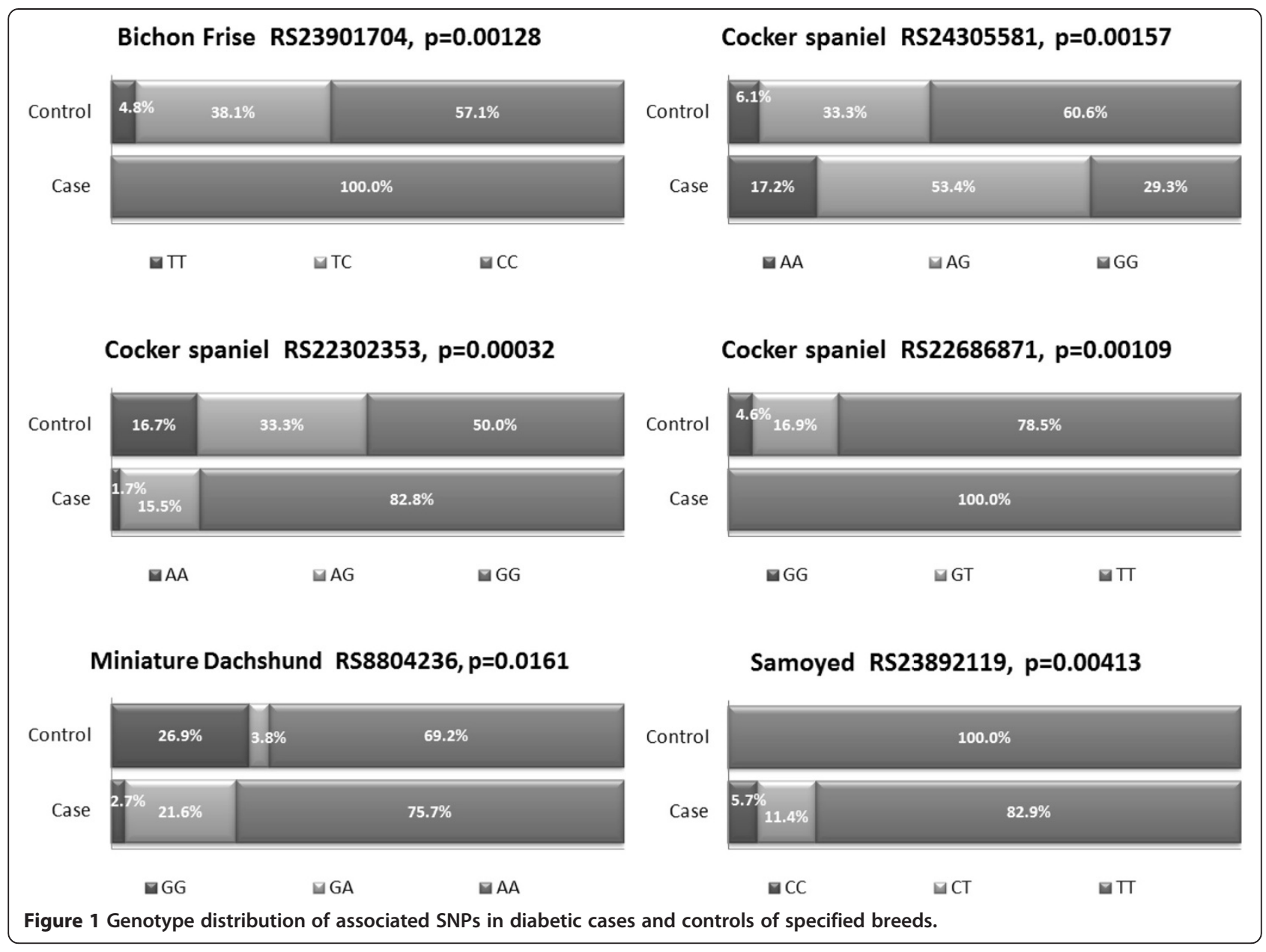

canine diabetes is a polygenic trait with multiple genes conferring susceptibility. They could suggest, however, that a proportion of the dogs within a breed have a monogenic form of diabetes and that the remainder of the breed have a polygenic form of the condition. This requires further investigation for better clarification.

Associations within the Cocker Spaniel breed could suggest that three types of monogenic diabetes co-exist within this breed if, for example, they were in LD with the causative SNP rather than being the actual causative SNP. This seems highly unlikely however, given the reported genetic uniformity of pedigree dog breeds, although genome-wide analysis (GWA) of Cocker Spaniels within our overall sample population has identified three distinct clusters of Cocker Spaniels when viewed on a multi-dimensional scaling plot (Jonathan Massey, unpublished data). The representation of three clusters following GWA indicates the presence of genetic stratification within the breed and could explain, in part, the association of three different genes, each representing a distinct type of diabetes within this breed in which the respective genes are contributory to diabetes susceptibility within a cluster but that other unidentified genes are also contributory.
The lack of GWA data on the specific dogs used in this candidate gene study prevents the stratification of this cohort into genome-wide sub-populations but could be a useful investigation strategy for future studies.

Three of the associated SNPs were intronic (rs24305581, rs22302353, rs23892119, Table 2) and while the specific function of these SNPs is unknown at the current time, intronic SNPs are known to affect gene expression through regulatory elements and have been shown to activate cryptic splice sites, leading to alternative splicing [56].

The other three associated SNPs were synonymous coding SNPs (rs23901704, rs22686871 rs8804236, Table 2) and it is well documented that synonymous SNPs affect gene function through mRNA splicing and can also affect precursor mRNA splicing, RNA stability and structure and protein folding. These synonymous SNPs could, therefore, result in ectopic mRNA splice sites and generate null, antagonising or agonistic protein isoforms leading to the diabetic disease phenotype. They could equally affect mRNA stability and subsequently the amount of available protein transcript could be increased or decreased or they could result in defective protein that do not function properly. 
The majority of breeds used in this analysis were not associated with the candidate genes that were selected. A monogenic type of diabetes could still exist within these breeds, but as yet the causative gene has not yet been identified. Alternatively it could be that the canine version of the causative gene was insufficiently annotated at the time of study and thus not included in the present study. An example of the latter is glucokinase which would be a good candidate gene, once the canine GCK sequence (XM_846042.2) and its chromosomal location have been better resolved (CanFam 3.1, http:// www.ncbi.nlm.nih.gov/gene/606490).

The limited number of associations with monogenic diabetes susceptibility genes could also indicate that canine diabetes is largely polygenic in most breeds and could also be subject to environmental influences. The finding of a small number of significant gene associations, and even some of the associations not retained following statistical correction, may indicate that these genes represent small risk contributions to a larger undiscovered polygenetic aetiology. This is further supported by the allele frequencies of the non-associated breeds in the study which are provided as additional information (Additional file 1: Table S1) and show that the associated alleles are often present in the other breeds but do not reach significance. In some breeds, the allele that is associated with diabetes in one breed is found at equal frequency in cases and controls of a different breed. For example, SNP rs23901704 showed an association to diabetes in the Samoyed (Table 2) with the minor allele $(C)$ being found at a frequency of 0.11 in the cases only. This same allele $(C)$ was found at similar frequencies for both controls and cases respectively in the Border collie (0.2 and 0.17), Labrador (0.17 vs. 0.22$)$, Miniature schnauzer (0.36 vs. 0.34 ), Samoyed (0.15 vs. 0.17) Springer Spaniel (0.08 vs. 0.12), West Highland white terrier (0.16 vs. 0.18$)$ and Yorkshire terrier (0.09 vs. 0.06$)$. Similar trends are seen for the other associated SNPs in the different breeds.

A number of immunity-related genes, including the dog leukocyte antigen (DLA) have already been associated with canine diabetes in some breeds [57-61]. This is not surprising, however, given the pathogenesis of the condition and the potential immune-mediated destruction of pancreatic beta cells. Many of the cytokine SNPs that have been associated with an increased risk of developing canine diabetes are from the Th2 subset [57-60]. This is important because the Th1-Th2 balance is considered to be instrumental in the development of this condition and diabetes is believed to be initiated by Th1 cytokines.

To achieve significant power in genome-wide association studies (GWAS) to identify genes and estimate the size of their contribution in complex polygenic conditions, human genetic analysis cohorts often require thousands of cases and controls. This is not the case in GWAS studies of pedigree dog breeds where the sample size may be as few as a hundred and power is increased when taking into account the small number of founder members for a given breed, the high level of inbreeding and the extended linkage disequilibrium and haplotype structure that exists in pedigree dog breeds [29]. It has been suggested that even fewer cases and an equal number of controls are sufficient to detect the disease allele for a simple Mendelian recessive trait [32]. With the exception of the Staffordshire bull terrier and Doberman, all of our breed cohorts contained more than 20 cases and controls, suggesting we should have had sufficient statistical power to detect associations for a monogenic disorder. The limited number of associations identified in this study is therefore most likely to be due to canine diabetes being a polygenic trait in most dog breeds.

This is the first multi-breed candidate gene analysis to investigate gene homologues in the dog that are equivalent to human monogenic forms of diabetes. We have evidence that some of the same genes that have been associated with susceptibility to MODY and NDM in humans are also associated with canine diabetes, although the number of breeds where this applies is limited and it is more likely that canine diabetes is a polygenic trait. Recruitment of cases or controls to such studies is difficult unless performed under a Home Office animal licence and most veterinary blood samples submitted to laboratories for DNA isolation are generally residual from other diagnostic tests.

\section{Conclusions}

The underlying aetiology and pathogenesis of canine diabetes have not been fully established and while insulin deficiency is a consistent feature, it remains a heterogeneous condition. The presence of specific breed predispositions and phenotypes within breeds suggests an underlying genetic basis for diabetes susceptibility but this susceptibility varies between breeds and is likely to result from the interactions of multiple genes. The current study and previous candidate gene studies have identified breed-specific genetic associations with the condition, but none of the identified associations can fully explain canine diabetes susceptibility. Ongoing GWA studies are expected to identify new loci that will further explain the breed susceptibility to diabetes in dogs.

\section{Methods}

\section{Study design}

Blood samples from diabetic dogs were selected from the UK Canine Diabetes Register and Archive (Royal Veterinary College, University of London). Diagnosis of diabetes was based on consistent clinical signs (polyuria, polydipsia and weight loss) and documented 
hyperglycaemia (i.e. $>9 \mathrm{mmol} / \mathrm{l}$ ) with glucosuria. Entire females were excluded from the study to eliminate dogs suffering from dioestrus diabetes, an insulin-resistance form of the disease. Dog samples representing seventeen breeds were selected from a larger collection of diabetic samples on the basis of providing a sample size $n \geq 15$ in each breed group (Table 1). Breed-matched, control samples (without diabetes) were selected from a large archive of DNA samples (http://www.liv.ac.uk/dna_archive_for_companion_animals/) UK DNA Archive for Companion
Animals, Universities of Manchester and Liverpool) which collects samples from animals being treated for a range of conditions. For this cohort, controls were selected as samples from dogs that were older than 7 years of age and had been diagnosed with (and were responding to treatment for) non-autoimmune, non-endocrine conditions. Conditions permitted for inclusion were those where the clinical signs were least likely to present with a diabetic phenotype and included, but was not limited to, hip dysplasia, cruciate rupture and neurological dysfunction (epilepsy). It was not

Table 3 Genes and SNPs used in the study and type of human monogenic diabetes that has been associated with the gene

\begin{tabular}{|c|c|c|c|c|c|}
\hline \multirow{2}{*}{$\frac{\text { Gene }}{A B C C 8}$} & \multirow{2}{*}{$\begin{array}{l}\text { Protein } \\
\text { Sulfonylurea receptor } 1\end{array}$} & \multicolumn{2}{|c|}{ SNP IDs } & \multirow{2}{*}{$\begin{array}{l}\text { Type of monogenic diabetes in humans } \\
\text { PNDM, TNDM }\end{array}$} & \multirow{2}{*}{$\frac{\text { Associated literature }}{[33]}$} \\
\hline & & rs9183439 & rs22988565 & & \\
\hline & & rs22993873 & rs9044450 & & [34] \\
\hline \multirow[t]{2}{*}{ BLK } & B lymphoid tyrosine kinase & rs23277058 & rs23242723 & MODY 11 & [35] \\
\hline & & rs23228211 & rs23268052 & & [36] \\
\hline \multirow[t]{2}{*}{ Cel } & Carboxyl ester lipase & rs8843005 & rs8843006 & MODY 8 (with exocrine dysfunction) & [37] \\
\hline & & rs24549495 & & & {$[38,39]$} \\
\hline \multirow[t]{2}{*}{ EIF2AK3 } & Eukaryotic translation & rs22578314 & rs9179252 & PNDM (with epiphyseal dysplasia) & [40] \\
\hline & initiation factor 2a kinase & rs22578182 & rs22566811 & & \\
\hline \multirow[t]{2}{*}{ FOXP3 } & Forkhead box P3 & rs24618205 & rs24596299 & PNDM (X-linked with immune-dysregulation, & [41] \\
\hline & & rs24612921 & & & [42] \\
\hline \multirow[t]{2}{*}{ HNF1A } & Hepatocyte nuclear factor 1a & rs23350532 & rs9013694 & MODY 3 & [43] \\
\hline & & rs23309484 & & & [20] \\
\hline \multirow[t]{2}{*}{ HNF1B } & Hepatocyte nuclear factor $1 \mathrm{~b}$ & rs24537168 & rs24585301 & MODY 5 (also with renal dysfunction, genital & [44] \\
\hline & & rs24537175 & rs24585484 & & \\
\hline \multirow[t]{3}{*}{ HNF4A } & Hepatocyte nuclear factor 4a & rs23214782 & rs23200327 & MODY 1 & [43] \\
\hline & & rs8804236 & rs23200360 & & [45] \\
\hline & & rs23214781 & rs9006559 & & [16] \\
\hline INS & Insulin & rs22686871 & & PNDM, MODY & [23] \\
\hline KLF11 & Kruppel-like factor 11 & rs22598321 & rs8803647 & MODY 7 & [46] \\
\hline \multirow[t]{2}{*}{ MTTL1 } & Transfer RNA for protein & rs8648077 & rs8884972 & Mitochondrial diabetes (maternally transmitted & [47] \\
\hline & translation & rs24305581 & & & [48] \\
\hline PAX4 & Paired box 4 & rs22302371 & rs22302353 & MODY 9 & [49] \\
\hline \multirow[t]{2}{*}{ PDX1 } & & rs8837751 & rs8837750 & MODY 4, PNDM (with pancreatic agenesis) & [50] \\
\hline & Insulin promoter factor 1 & & rs23247540 & & [21] \\
\hline \multirow[t]{2}{*}{ PTF1A } & Pancreas-specific & rs8955054 & rs8955053 & PNDM (with pancreatic and cerebellar agenesis) & [51] \\
\hline & transcription factor 1a & rs8955055 & & & \\
\hline \multirow[t]{2}{*}{ RFX6 } & Regulatory factor X6 & rs8928516 & rs21958946 & PNDM (with hypoplastic pancreas and gall bladder, & [52] \\
\hline & & rs21890992 & & & \\
\hline \multirow[t]{2}{*}{ WFS1 } & & rs24739532 & & PNDM (with diabetes insipidus, optic atrophy, & [53] \\
\hline & Wolframin & & & $\mathrm{d}$ & [54] \\
\hline \multirow[t]{2}{*}{ ZFP57 } & Zinc finger protein 57 & rs23901704 & rs23892119 & TNDM & [55] \\
\hline & & rs23892118 & rs23901705 & & \\
\hline ZAC1/PLAG1 & $\begin{array}{l}\text { Pleiomorphic adenoma } \\
\text { gene-like } 1\end{array}$ & rs23483681 & & TNDM & \\
\hline
\end{tabular}


possible to test for hyperglycaemia in these retrospectively recruited samples. Control samples were selected from the same geographical region as that for the dogs with diabetes, wherever possible.

Sex and neutered status were not available for all of the control dogs thus eliminating the possibility of investigating sex bias and it was not possible to assess the relatedness of affected dogs as UK Kennel Club registration numbers were not available for the majority of dogs investigated. Allelic association was conducted in a breed-bybreed manner.

\section{DNA extraction}

DNA was extracted from residual EDTA blood samples using either a standard phenol: chloroform method or a Qiagen QIAamp DNA Blood Midi Kit in accordance with the manufacturer's instructions. DNA quality (A260:280) and concentration were measured using a NanoDrop (www.nanodrop.com/). All samples had a 260:280 ratio between 1.6 and 1.9 were diluted to a final concentration of $5 \mathrm{ng} / \mu \mathrm{l}$ for SNP genotyping.

\section{Candidate gene and SNP selection}

Nineteen candidate genes were chosen based on reported associations to human forms of monogenic diabetes (Table 3). A total of 65 SNPs were genotyped with SNP selection being prioritised for inclusion if they were non-synonymous or synonymous coding SNPs or were located in the 3'or 5' UTR. Intronic SNPs were included in the absence of coding/UTR SNPs and were selected as those being closest to the intron/exon boundaries on the assumption that 'within breed' linkage disequilibrium would extend across the boundaries, as opposed to conservation or the presence of regulatory elements. The SNPs used in the analyses are shown in Table 3.

\section{Sequenom genotyping}

Primers and probes were designed using Sequenom Assay Design software Version 3, and synthesised by SigmaAldrich (Poole, UK). Primers were diluted to $100 \mu \mathrm{M}$ and plexes pooled to contain $500 \mathrm{~nm}$ of each forward and reverse primer. Probes were diluted to $400 \mu \mathrm{M}$ and probe pools were split into four tiers dependent upon mass. Probe pools were split into four equal tiers containing $26 \mu \mathrm{l}, 35 \mu \mathrm{l}, 43 \mu \mathrm{l}$ and $52 \mu \mathrm{l}$ of probe (low to high mass), in a final volume of $1.5 \mathrm{ml}$.

PCR reactions contained 20 ng DNA plated into a 384 well plate. PCRs were performed in $5 \mu \mathrm{l}$ volumes using an ABI 9700 cycler (384 well). Reactions contained $0.625 \mu \mathrm{l}$ of $10 \times$ PCR buffer (with $20 \mathrm{mM} \mathrm{MgCl}$, Roche), $0.2 \mu \mathrm{l}$ of $\mathrm{MgCl}_{2}(25 \mathrm{mM}), 0.25 \mu \mathrm{l}$ of dNTPs $(10 \mathrm{mM}), 100 \mathrm{nM}$ of forward and reverse primer plex, $0.1 \mu$ l FastStart Taq (5 U/ $\mu \mathrm{l}$, Roche) and were amplified as follows: $95^{\circ} \mathrm{C}$ for 5 minutes; 40 cycles of $95^{\circ} \mathrm{C}$ for 20 seconds, $56^{\circ} \mathrm{C}$ for 30 seconds, $72^{\circ} \mathrm{C}$ for 1 minute; $72^{\circ} \mathrm{C}$ for 3 minutes. Following PCR, reactions were treated with $0.3 \mathrm{U} / \mu \mathrm{l}$ shrimp alkaline phosphatase (SAP) to dephosphorylate remaining dNTPs. Reactions were incubated at $37^{\circ} \mathrm{C}$ for 40 minutes, and denatured at $85^{\circ} \mathrm{C}$ for 5 minutes. iPLEX primer extension was carried out using an ABI 9700 PCR engine. Reactions contained $0.22 \times$ iPLEX buffer, $1 \mathrm{x}$ iPLEX termination mix, primers adjusted for concentration using a four tier method $(0.625 \mu \mathrm{M}, 0.83 \mu \mathrm{M}, 1.04 \mu \mathrm{M}$, and $1.25 \mu \mathrm{M})$ and $1 \times$ iPLEX enzyme, and were amplified as follows: $94^{\circ} \mathrm{C}$ for 30 seconds, 40 cycles of $94^{\circ} \mathrm{C}$ for 5 seconds, 5 cycles of $52^{\circ} \mathrm{C}$ for 5 seconds, $80^{\circ} \mathrm{C}$ for 5 seconds, and a final extension of $72^{\circ} \mathrm{C}$ for 3 minutes. Samples were diluted with $20 \mu \mathrm{l}$ water and desalted using $6 \mathrm{mg}$ resin before being centrifuged for 5 minutes at 4,000 rpm and spotted onto a SpectroCHIP using a Sequenom mass array nanodispenser (Samsung).

\section{Allelic association analyses}

Association analyses and quality checks were carried out using PLINK [62]. Hardy-Weinberg equilibrium (HWE) was checked for each breed control group and call rates were determined for cases and controls for each breed, independently. SNPs in which the control population was out of HWE and/or the call rate was below $90 \%$ were excluded from the analyses. Samples were excluded if the call rate was below $90 \%$. Permutation testing and Bonferroni correction were applied to raw $\mathrm{p}$ values and SNPs were deemed statistically significant if $p_{\text {corrected }}<0.05$.

Markers showing allelic association were also tested for a genotype association.

\section{Additional file}

Additional file 1: Table S1. Minor allele frequencies for each breed. Table shows the minor allele, its frequency in controls and cases and the major allele for each marker in each breed. The number of controls and cases that were genotyped and passed QC is also shown.

\section{Competing interests}

The authors declare that they have no competing interests.

\section{Authors' contributions}

ADS: Study design, SNP selection, data quality and analysis, manuscript preparation. AH: Diabetes diagnosis of affected dogs and sample collection. SR: DNA extraction and quality checking. JM: Assay design, SNP genotyping. RS: Assay design, SNP genotyping. BC: Study conception and design, diabetes diagnosis of affected dogs and sample collection, critical evaluation of manuscript. LJK: Study conception and design. WERO: Study conception and design, critical evaluation of manuscript. All authors read and approved the final manuscript.

\section{Acknowledgements}

The UK Canine Diabetes Register and Archive has been supported by the Kennel Club Charitable Trust, Petsavers, the European Commission (FP7-LUPA, GA-201370; www.eurolupa.org) and MSD Animal Health. We are grateful to the UK Animal DNA Archive for Companion animals for providing the DNA for many of the samples. We would also like to thank the owners 
of dogs with diabetes and control dogs, who gave permission for their dogs to participate in this study.

\section{Author details}

${ }^{1}$ Centre for Integrated Genomic Medical Research, University of Manchester, Stopford Building, Oxford Road, Manchester M13 9PT, UK. ${ }^{2}$ Department of Pathology and Pathogen Biology, Royal Veterinary College, Hawkshead Lane, North Mymms, Hatfield, Herts AL9 7TA, UK.

\section{Received: 13 March 2014 Accepted: 23 June 2014}

Published: 7 July 2014

\section{References}

1. Mattheeuws D, Rottiers R, Kaneko JJ, Vermeulen A: Diabetes mellitus in dogs: relationship of obesity to glucose tolerance and insulin response. Am J Vet Res 1984, 45(1):98-103.

2. Davison LJ, Herrtage ME, Catchpole B: Study of 253 dogs in the United Kingdom with diabetes mellitus. Vet Rec 2005, 156(15):467-471.

3. Davison LJ, Ristic JM, Herrtage ME, Ramsey IK, Catchpole B: Anti-insulin antibodies in dogs with naturally occurring diabetes mellitus. Vet Immunol Immunopathol 2003, 91(1):53-60.

4. Catchpole B, Kennedy L, Davison LJ, Ollier WE: Canine diabetes mellitus: from phenotype to genotype. J Small Anim Pract 2008, 49(1):4-10.

5. Papa K, Mathe A, Bonyi-Toth Z, Sterczer A, Psader R, Hetyey C, Vajdovich P, Voros K: Occurrence, clinical features and outcome of canine pancreatitis (80 cases). Acta Vet Hung 2011, 59(1):37.

6. Watson PJ, Archer J, Roulois AJ, Scase TJ, Herrtage ME: Observational study of 14 cases of chronic pancreatitis in dogs. Vet Rec 2010, 167(25):968-976.

7. Davison LJ, Weenink SM, Christie MR, Herrtage ME, Catchpole B: Autoantibodies to GAD65 and IA-2 in canine diabetes mellitus. Vet Immunol Immunopathol 2008, 126(1-2):83-90.

8. Fleeman LM, Rand JS: Management of canine diabetes. Vet Clin North Am Small Anim Pract 2001, 31(5):855-880.

9. Davis TM: Ethnic diversity in type 2 diabetes. Diabet Med 2008 25(2):52-56. doi:10.1111/j.1464-5491.2008.02499.x., pp. 52-56.

10. Marmor M, Willeberg P, Glickman LT, Priester WA, Cypess RH, Hurvitz Al: Epizootiologic patterns of diabetes mellitus in dogs. Am J Vet Res 1982, 43(3):465-470

11. Hess RS, Kass PH, Ward CR: Breed distribution of dogs with diabetes mellitus admitted to a tertiary care facility. I Am Vet Med Assoc 2000 216:1414-1417.

12. Kramer JW, Klaassen JK, Baskin DG, Prieur DJ, Rantanen NW, Robinette JD, Graber WR, Rashti L: Inheritance of diabetes mellitus in Keeshond dogs. Am J Vet Res 1988, 49(3):428-431.

13. Fall T, Hamlin HH, Hedhammar A, Kampe O, Egenvall A: Diabetes mellitus in a population of 180,000 insured dogs: incidence, survival, and breed distribution. J Vet Intern Med 2007, 21(6):1209-1216.

14. Chen R, Corona E, Sikora M, Dudley JT, Morgan AA, Moreno-Estrada A, Nilsen GB, Ruau D, Lincoln SE, Bustamante CD, Butte AJ: Type 2 diabetes risk alleles demonstrate extreme directional differentiation among human populations, compared to other diseases. PLoS Genet 2012, 8(4):e1002621.

15. Steck AK, Bugawan TL, Valdes AM, Emery LM, Blair A, Norris JM, Redondo MJ, Babu SR, Erlich HA, Eisenbarth GS, Rewers MJ: Association of non-HLA genes with type 1 diabetes autoimmunity. Diabetes 2005, 54(8):2482-2486.

16. Yamagata K, Furuta H, Oda N, Kaisaki PJ, Menzel S, Cox NJ, Fajans SS, Signorini S, Stoffel M, Bell Gl: Mutations in the hepatocyte nuclear factor-4alpha gene in maturity-onset diabetes of the young (MODY1). Nature 1996, 384(6608):458-460.

17. Cao H, Shorey S, Robinson J, Metzger DL, Stewart L, Cummings E, Hegele RA: GCK and HNF1A mutations in Canadian families with maturity onset diabetes of the young (MODY). Hum Mutat 2002, 20(6):478-479.

18. Pruhova S, Ek J, Lebl J, Sumnik Z, Saudek F, Andel M, Pedersen O, Hansen T: Genetic epidemiology of MODY in the Czech republic: new mutations in the MODY genes HNF-4alpha, GCK and HNF-1alpha. Diabetologia 2003, 46(2):291-295.

19. Ellard S: Hepatocyte nuclear factor 1 alpha (HNF-1 alpha) mutations in maturity-onset diabetes of the young. Hum Mutat 2000, 16(5):377-385.

20. Yamagata K, Oda N, Kaisaki PJ, Menzel S, Furuta H, Vaxillaire M, Southam L, Cox RD, Lathrop GM, Boriraj W, Chen X, Cox NJ, Oda Y, Yano H, Le Beau MM, Yamada S, Nishigori H, Takeda J, Fajans SS, Hattersley AT, Iwasaki N, Hansen T, Pedersen O, Polonsky KS, Bell Gl: Mutations in the hepatocyte nuclear factor-1alpha gene in maturity-onset diabetes of the young (MODY3). Nature 1996, 384(no. 6608):455-458.

21. Stoffers DA, Ferrer J, Clarke WL, Habener JF: Early-onset type-II diabetes mellitus (MODY4) linked to IPF1. Nat Genet 1997, 17(2):138-139.

22. Wang L, Coffinier C, Thomas MK, Gresh L, Eddu G, Manor T, Levitsky LL, Yaniv M, Rhoads DB: Selective deletion of the Hnf1 beta (MODY5) gene in beta-cells leads to altered gene expression and defective insulin release. Endocrinology 2004, 145(8):3941-3949.

23. Edghill EL, Flanagan SE, Patch AM, Boustred C, Parrish A, Shields B, Shepherd MH, Hussain K, Kapoor RR, Malecki M, MacDonald MJ, Stoy J, Steiner DF, Philipson LH, Bell Gl, Hattersley AT, Ellard S: Insulin mutation screening in 1,044 patients with diabetes: mutations in the INS gene are a common cause of neonatal diabetes but a rare cause of diabetes diagnosed in childhood or adulthood. Diabetes 2008, 57(4):1034-1042.

24. Stoy J, Steiner DF, Park SY, Ye H, Philipson LH, Bell GI: Clinical and molecular genetics of neonatal diabetes due to mutations in the insulin gene. Rev Endocr Metab Disord 2010, 11(3):205-215.

25. Hussain K: Mutations in pancreatic ss-cell Glucokinase as a cause of hyperinsulinaemic hypoglycaemia and neonatal diabetes mellitus. Rev Endocr Metab Disord 2010, 11(3):179-183.

26. Catchpole B, Adams JP, Holder AL, Short AD, Ollier WE, Kennedy LJ: Genetics of canine diabetes mellitus: are the diabetes susceptibility genes identified in humans involved in breed susceptibility to diabetes mellitus in dogs? Vet J 2013, 195(2):139-147.

27. Atkins CE, LeCompte PM, Chin HP, Hill JR, Ownby CL, Brownfield MS: Morphologic and immunocytochemical study of young dogs with diabetes mellitus associated with pancreatic islet hypoplasia. Am J Vet Res 1988, 49(9):1577-1581.

28. Ramirez-Soriano A, Lao O, Soldevila M, Calafell F, Bertranpetit J, Comas D: Haplotype tagging efficiency in worldwide populations in CTLA4 gene. Genes Immun 2005, 6(8):646-657.

29. Lindblad-Toh K, Wade CM, Mikkelsen TS, Karlsson EK, Jaffe DB, Kamal M, Clamp M, Chang JL, Kulbokas EJ II, Zody MC, Mauceli E, Xie X, Breen M, Wayne RK, Ostrander EA, Ponting CP, Galibert F, Smith DR, DeJong PJ, Kirkness E, Alvarez P, Biagi T, Brockman W, Butler J, Chin CW, Cook A, Cuff J, Daly MJ, DeCaprio D, Gnerre $S$, et al: Genome sequence, comparative analysis and haplotype structure of the domestic dog. Nature 2005, 438(no. 7069):803-819.

30. Ostrander EA, Comstock KE: The domestic dog genome. Curr Biol 2004, 14(3):R98-R99.

31. Sutter NB, Ostrander EA: Dog star rising: the canine genetic system. Nat Rev Genet 2004, 5(12):900-910.

32. Karlsson EK, Lindblad-Toh K: Leader of the pack: gene mapping in dogs and other model organisms. Nat Rev Genet 2008, 9(9):713-725.

33. Ellard S, Flanagan SE, Girard CA, Patch AM, Harries LW, Parrish A, Edghill EL, Mackay DJ, Proks P, Shimomura K, Haberland H, Carson DJ, Shield JP, Hattersley AT, Ashcroft FM: Permanent neonatal diabetes caused by dominant, recessive, or compound heterozygous SUR1 mutations with opposite functional effects. Am J Hum Genet 2007, 81(2):375-382.

34. Babenko AP, Polak M, Cave H, Busiah K, Czernichow P, Scharfmann R, Bryan J, Guilar-Bryan L, Vaxillaire $M$, Froguel P: Activating mutations in the ABCC8 gene in neonatal diabetes mellitus. N Engl J Med 2006, 355(5):456-466.

35. Bonnefond A, Yengo L, Philippe J, Dechaume A, Ezzidi I, Vaillant E, Gjesing AP, Andersson EA, Czernichow S, Hercberg S, Hadjadj S, Charpentier G, Lantieri O, Balkau B, Marre M, Pedersen O, Hansen T, Froguel P, Vaxillaire M: Reassessment of the putative role of BLK-p.A71T loss-of-function mutation in MODY and type 2 diabetes. Diabetologia 2013, 56(3):492-496.

36. Borowiec M, Liew CW, Thompson R, Boonyasrisawat W, Hu J, Mlynarski WM, El Khattabi I, Kim SH, Marselli L, Rich SS, Krolewski AS, Bonner-Weir S, Sharma A, Sale M, Mychaleckyj JC, Kulkarni RN, Doria A: Mutations at the BLK locus linked to maturity onset diabetes of the young and beta-cell dysfunction. Proc Natl Acad Sci U S A 2009, 106(34):14460-14465.

37. Torsvik J, Johansson S, Johansen A, Ek J, Minton J, Raeder H, Ellard S, Hattersley A, Pedersen O, Hansen T, Molven A, Njolstad PR: Mutations in the VNTR of the carboxyl-ester lipase gene (CEL) are a rare cause of monogenic diabetes. Hum Genet 2010, 127(1):55-64.

38. Raeder H, Johansson S, Holm PI, Haldorsen IS, Mas E, Sbarra V, Nermoen I, Eide SA, Grevle L, Bjorkhaug L, Sagen JV, Aksnes L, Sovik O, Lombardo D, Molven A, Njolstad PR: Mutations in the CEL VNTR cause a syndrome of diabetes and pancreatic exocrine dysfunction. Nat Genet 2006, 38(1):54-62 
39. Raeder H, Vesterhus M, El OA, Paulo JA, McAllister FE, Liew CW, Hu J, Kawamori D, Molven A, Gygi SP, Njolstad PR, Kahn CR, Kulkarni RN: Absence of diabetes and pancreatic exocrine dysfunction in a transgenic model of carboxyl-ester lipase-MODY (maturity-onset diabetes of the young). PLOS ONE 2013, no. 4(4):e60229.

40. Delepine M, Nicolino M, Barrett T, Golamaully M, Lathrop GM, Julier C: EIF2AK3, encoding translation initiation factor 2-alpha kinase 3, is mutated in patients with Wolcott-Rallison syndrome. Nat Genet 2000, 25(4):406-409.

41. Bennett CL, Christie J, Ramsdell F, Brunkow ME, Ferguson PJ, Whitesell L Kelly TE, Saulsbury FT, Chance PF, Ochs HD: The immune dysregulation, polyendocrinopathy, enteropathy, X-linked syndrome (IPEX) is caused by mutations of FOXP3. Nat Genet 2001, 27(1):20-21.

42. Wildin RS, Ramsdell F, Peake J, Faravelli F, Casanova JL, Buist N, Levy-Lahad E, Mazzella M, Goulet O, Perroni L, Bricarelli FD, Byrne G, McEuen M, Proll S, Appleby M, Brunkow ME: X-linked neonatal diabetes mellitus, enteropathy and endocrinopathy syndrome is the human equivalent of mouse scurfy. Nat Genet 2001, 27(1):18-20.

43. Colclough K, Bellanne-Chantelot C, Saint-Martin C, Flanagan SE, Ellard S: Mutations in the genes encoding the transcription factors hepatocyte nuclear factor 1 alpha and 4 alpha in maturity-onset diabetes of the young and hyperinsulinemic hypoglycemia. Hum Mutat 2013, 34(5):669-685.

44. Horikawa Y, Iwasaki N, Hara M, Furuta H, Hinokio Y, Cockburn BN, Lindner T, Yamagata K, Ogata M, Tomonaga O, Kuroki H, Kasahara T, Iwamoto Y, Bell Gl: Mutation in hepatocyte nuclear factor-1 beta gene (TCF2) associated with MODY. Nat Genet 1997, 17(4):384-385.

45. Bulman MP, Dronsfield MJ, Frayling T, Appleton M, Bain SC, Ellard S, Hattersley AT: A missense mutation in the hepatocyte nuclear factor 4 alpha gene in a UK pedigree with maturity-onset diabetes of the young. Diabetologia 1997, 40(7):859-862.

46. Neve B, Fernandez-Zapico ME, Shkenazi-Katalan V, Dina C, Hamid YH, Joly E, Vaillant E, Benmezroua Y, Durand E, Bakaher N, Delannoy V, Vaxillaire M,

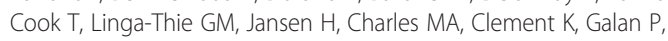
Hercberg S, Helbecque N, Charpentier G, Prentki M, Hansen T, Pedersen O, Urrutia R, Melloul D, Froguel P: Role of transcription factor KLF11 and its diabetes-associated gene variants in pancreatic beta cell function. Proc Natl Acad Sci U S A 2005, 102(no. 13):4807-4812.

47. Murphy R, Turnbull DM, Walker M, Hattersley AT: Clinical features, diagnosis and management of maternally inherited diabetes and deafness (MIDD) associated with the $3243 \mathrm{~A}>\mathrm{G}$ mitochondrial point mutation. Diabet Med 2008, 25(4):383-399.

48. van den Ouweland JM, Lemkes HH, Ruitenbeek W, Sandkuijl LA, de Vijlder MF, Struyvenberg PA, van de Kamp JJ, Maassen JA: Mutation in mitochondrial tRNA(Leu)(UUR) gene in a large pedigree with maternally transmitted type II diabetes mellitus and deafness. Nat Genet 1992, 1(5):368-371.

49. Plengvidhya N, Kooptiwut S, Songtawee N, Doi A, Furuta H, Nishi M, Nanjo K, Tantibhedhyangkul W, Boonyasrisawat W, Yenchitsomanus PT, Doria A, Banchuin N: PAX4 mutations in Thais with maturity onset diabetes of the young. J Clin Endocrinol Metab 2007, 92(7):2821-2826.

50. De FE, Shaw-Smith C, Flanagan SE, Edghill EL, Wolf J, Otte V, Ebinger F, Varthakavi P, Vasanthi T, Edvardsson S, Hattersley AT, Ellard S: Biallelic PDX1 (insulin promoter factor 1) mutations causing neonatal diabetes without exocrine pancreatic insufficiency. Diabet Med 2013, 30(5):e197-e200.

51. Sellick GS, Barker KT, Stolte-Dijkstra I, Fleischmann C, Coleman RJ, Garrett C, Gloyn AL, Edghill EL, Hattersley AT, Wellauer PK, Goodwin G, Houlston RS: Mutations in PTF1A cause pancreatic and cerebellar agenesis. Nat Genet 2004, 36(12):1301-1305.

52. Smith SB, Qu HQ, Taleb N, Kishimoto NY, Scheel DW, Lu Y, Patch AM, Grabs R, Wang J, Lynn FC, Miyatsuka T, Mitchell J, Seerke R, Desir J, Vanden ES, Abramowicz M, Kacet N, Weill J, Renard ME, Gentile M, Hansen I, Dewar K, Hattersley AT, Wang R, Wilson ME, Johnson JD, Polychronakos C, German MS: Rfx6 directs islet formation and insulin production in mice and humans. Nature 2010, 463(7282):775-780.

53. Strom TM, Hortnagel K, Hofmann S, Gekeler F, Scharfe C, Rabl W, Gerbitz KD, Meitinger T: Diabetes insipidus, diabetes mellitus, optic atrophy and deafness (DIDMOAD) caused by mutations in a novel gene (wolframin) coding for a predicted transmembrane protein. Hum Mol Genet 1998, 7(13):2021-2028.

54. Inoue H, Tanizawa Y, Wasson J, Behn P, Kalidas K, Bernal-Mizrachi E, Mueckler M, Marshall H, Donis-Keller H, Crock P, Rogers D, Mikuni M, Kumashiro H, Higashi K, Sobue G, Oka Y, Permutt MA: A gene encoding a transmembrane protein is mutated in patients with diabetes mellitus and optic atrophy (Wolfram syndrome). Nat Genet 1998, 20(2):143-148.

55. Mackay DJ, Callaway JL, Marks SM, White HE, Acerini CL, Boonen SE, Dayanikli P, Firth HV, Goodship JA, Haemers AP, Hahnemann JM, Kordonouri O, Masoud AF, Oestergaard E, Storr J, Ellard S, Hattersley AT, Robinson DO, Temple IK: Hypomethylation of multiple imprinted loci in individuals with transient neonatal diabetes is associated with mutations in ZFP57. Nat Genet 2008, 40(8):949-951.

56. George Priya DC, Sudandiradoss C, Rajasekaran R, Choudhury P, Sinha P, Hota P, Batra UP, Rao S: Applications of computational algorithm tools to identify functional SNPs. Funct Integr Genomics 2008, 8(4):309-316.

57. Short AD: The Genetics of Canine Diabetes: A Candidate Gene Study. In PhD Thesis. Manchester: University of Manchester; 2006

58. Short AD, Catchpole B, Kennedy LJ, Barnes A, Fretwell N, Jones C, Thomson W, Ollier WER: Analysis of candidate susceptibility genes in canine diabetes. J Hered 2007, 98(5):518-525.

59. Short AD, Catchpole B, Kennedy LJ, Barnes A, Lee AC, Jones CA, Fretwell N, Ollier WE: T cell cytokine gene polymorphisms in canine diabetes mellitus. Vet Immunol Immunopathol 2008, 128:137-146.

60. Short AD, Saleh NM, Catchpole B, Kennedy $\amalg$, Barnes A, Jones CA Fretwell N, Ollier WE: CTLA4 promoter polymorphisms are associated with canine diabetes mellitus. Tissue Antigens 2010, 75(3):242-252

61. Kennedy LJ, Davison $\sqcup$, Barnes A, Short AD, Fretwell N, Jones CA, Lee AC, Ollier WE, Catchpole B: Identification of susceptibility and protective major histocompatibility complex haplotypes in canine diabetes mellitus. Tissue Antigens 2006, 68(6):467-476.

62. Purcell S, Neale B, Todd-Brown K, Thomas L, Ferreira MA, Bender D, Maller J, Sklar P, de Bakker PI, Daly MJ, Sham PC: PLINK: a tool set for whole-genome association and population-based linkage analyses. Am J Hum Genet 2007, 81(3):559-575.

doi:10.1186/2052-6687-1-8

Cite this article as: Short et al: Searching for "monogenic diabetes" in dogs using a candidate gene approach. Canine Genetics and Epidemiology 2014 1:8.

\section{Submit your next manuscript to BioMed Central and take full advantage of:}

- Convenient online submission

- Thorough peer review

- No space constraints or color figure charges

- Immediate publication on acceptance

- Inclusion in PubMed, CAS, Scopus and Google Scholar

- Research which is freely available for redistribution 